\title{
Resenha: Relacionamento Professor-Aluno e Práticas Pedagógicas
}

\author{
Marco Aurélio Togatlian ${ }^{1}$ \\ Universidade Federal do Espírito Santo
}

\section{Book Review: Relationship between Teacher-Student and Practical Pedagogical}

Entre as muitas facetas do cenário da educação brasileira, a relação entre afetividade e práticas pedagógicas merece destaque. É justamente este o tema do livro organizado por Sérgio Antonio da Silva Leite (2006). O principal argumento da obra é baseado no pressuposto de que as relações que se estabelecem entre o sujeito e o objeto do conhecimento não são apenas de natureza cognitiva, mas também afetiva e dependem da qualidade da história das mediações vivenciadas pelo sujeito em relação ao objeto. A obra interessa aos profissionais da Educação, da Psicologia, e a todos preocupados com a otimização da aprendizagem, principalmente no que se refere ao relacionamento professor-aluno.

O livro está organizado em três partes: a primeira reúne sete capítulos que relatam pesquisas relacionadas à afetividade nas práticas pedagógicas. Os textos englobam desde o enfoque mais genérico sobre a relação professor-aluno até pontos mais específicos como a postura de professores de classes de alfabetização. A segunda parte, composta por três capítulos, focaliza a afetividade relacionada à formação do leitor e o único capítulo da terceira parte relaciona afetividade e formação de professores.

A questão da afetividade na prática docente é tratada em todos os capítulos da obra sob a perspectiva da mediação - conceito definido por Vygotsky (1994) e também sob o olhar de Wallon (1978) - para quem afetividade e cognição não são funções antagônicas uma à outra. O primeiro capítulo, de autoria do próprio organizador, procura situar o leitor em torno do tema. A questão central ressalta que todas as decisões pedagógicas que o professor assume no planejamento e desenvolvimento do seu trabalho têm implicações diretas tanto no nível cognitivo quanto no afetivo e que a qualidade da mediação vivenciada pelo aluno pode influenciar toda a história da futura relação entre ele e os diversos conteúdos estudados. A afetividade é tratada aqui sob dois enfoques: afetividade na relação professor - aluno e afetividade nas condições de ensino.

O segundo capítulo, escrito pela professora Elvira Tassoni, examina, a partir de relatos verbais, as interações entre professoras e alunos de uma escola particular de Campinas (alunos de 6 anos). A autora conclui que a promoção de relações harmoniosas em sala de aula não implica que o professor tenha que se destituir da sua autoridade e hierarquia, não havendo incompatibilidade entre estes aspectos e o vínculo afetivo. A pedagoga Daniela Falcin aborda no terceiro capítulo a relação entre afetividade e condições de ensino, discutindo histórias de professores inesquecíveis

1 Endereço: Av. Comte Bitencourt 110/301, Centro, Nova Friburgo, RJ, Brasil, 28625-00.E-mail:marco@togatlian.pro.br identificados pelos alunos do terceiro ano do ensino médio e como essas dimensões afetivas influenciaram positivamente a relação entre eles e os conteúdos escolares. No capítulo seguinte, a professora Ariane Tagliaferro relata uma pesquisa sobre o único professor de Língua Portuguesa, docente de uma cidade no interior de São Paulo, reconhecido por seus alunos como um professor inesquecível.

O quinto capítulo, de autoria da professora Samanta Kager, trata da relação entre avaliação e afetividade, percebendo a primeira como uma prática pedagógica rotineira influindo na relação do aluno do ensino médio com o conhecimento a partir de seus relatos com experiências escolares negativas. A avaliação é vista como uma dimensão da mediação pedagógica, envolvendo a dimensão afetiva e não se restringindo apenas às questões cognitivas. O capítulo seguinte, escrito pela professora Flávia Regina de Barros, narra as histórias de dois sujeitos, que experimentaram uma mudança radical em suas relações com o objeto do conhecimento, antes marcadas por dificuldades, frente a novas relações de mediação, especificamente nas disciplinas de História e Língua Portuguesa. João, universitário do curso de Ciências Sociais, experimentou uma relação aversiva com a disciplina de História, da $5^{\mathrm{a}}$ série do Ensino Fundamental até o $1^{\circ}$ ano do Ensino Médio. Rodrigo, universitário de Engenharia da Computação, vivenciou a experiência aversiva com a disciplina Língua Portuguesa da $5^{\mathrm{a}}$ a $8^{\mathrm{a}}$ série do Ensino Fundamental. O capítulo descreve como ocorreram as transformações em relação à forma de perceberem tais disciplinas e o papel desempenhado pelos professores de ambos na referida transformação.

O último capítulo da primeira parte aborda a afetividade nas atividades de ensino em classes de alfabetização, especificamente quanto à natureza das interações entre professor $\mathrm{e}$ aluno. A pedagoga Fabiana Colombo organiza os dados em núcleos temáticos verbais e não-verbais. Os núcleos temáticos verbais referem-se aos conteúdos verbais emitidos pela professora, nos quais se identificam as dimensões afetivas de sua mediação por meio do tom, da modulação de sua voz e dos conteúdos de suas verbalizações, no momento da interação com as crianças, por exemplo: elogio, instrução, incentivo, entre outros. Os núcleos temáticos não-verbais incluem os gestos e posturas da professora em relação à criança, caracterizando-se em ações, expressões corporais e faciais, por exemplo: aproximação, contato físico, receptividade, entre outros. De acordo com a disposição dos núcleos temáticos, foi possível inferir que as dimensões afetivas estão sempre presentes na interação entre professor e aluno, o que remete ao conceito de mediação de Vygotsky.

A segunda parte do livro é dedicada às questões que envolvem a afetividade e a formação do leitor. No primeiro 


\section{A. Togatlian}

capítulo, a professora e mestre em psicologia Ellen Cristina Grotta relata histórias de vida de quatro leitores (professores universitários com idade entre 40 e 60 anos) enfocando os aspectos determinantes em sua formação como leitores. $\mathrm{O}$ segundo capítulo, de autoria da professora Juliana Simões de Souza, discute o papel do "outro", notadamente da família, na formação do leitor, a partir de informações obtidas de quatro jovens considerados como leitores de sucesso, isto é, que liam por prazer e constantemente. A conclusão é que a família foi responsável por uma mediação de qualidade entre os participantes e a leitura. Como consequiência, os mesmos puderam experimentar situações agradáveis no ato de ler, o que determinou a formação leitores autônomos. No último capítulo, a professora e mestre em Educação Lílian Silva discute os relatos de alunos-leitores do ensino fundamental sobre as experiências de leitura oferecidas em suas escolas. A autora conclui que o interesse do aluno pela leitura depende diretamente das estratégias que os professores utilizam para aproximar o livro dos alunos e que estes procedimentos influenciarão a vida do aluno como leitor.

$\mathrm{Na}$ terceira parte do livro, a professora Maria Cristina Pellisson analisa o papel da afetividade no processo de formação de uma professora do ensino fundamental. Desde a infância até a busca pela universidade, a história de uma professora é narrada através da presença da afetividade na constituição do sujeito, aluno e professora, principalmente por meio de reflexões pessoais durante o processo de formação docente e da prática profissional.

Diante das questões que se colocam no cenário da educação brasileira, o relacionamento professor/aluno merece destaque. As diversas práticas pedagógicas exaustivamente estudadas por professores e educadores sempre esbarram nesta questão. $\mathrm{O}$ cenário observado neste âmbito ainda não é animador, percebe-se que as questões de caráter técnico ou mesmo conteudistas, ainda se sobrepõem às de enfoque relacional, as pesquisas referentes a estas são minoria no âmbito educacional, por isso a reflexão sobre o tema é ainda mais necessária.

O livro representa uma contribuição importante para a psicologia e para a pedagogia, especialmente para os pesquisadores do relacionamento entre professor e aluno e seu papel no processo de ensino e aprendizagem, indicando como fatores sociais, afetivos e cognitivos estão intimamente relacionados, não podendo ser vistos como fenômenos separados, nem no âmbito das práticas pedagógicas, nem no âmbito das relações interpessoais. Para os docentes, a obra possui importância especial, pois estuda as múltiplas possibilidades de influências que o professor pode representar, refletindo sobre a percepção dos alunos em relação às diversas áreas do conhecimento em suas vidas futuras.

\section{Referências}

Leite, S.A. da S. (Org.) (2006). Afetividade e Práticas Pedagógicas. São Paulo: Casa do Psicólogo.

Vygotsky, L.S. (1994). A formação social da mente. São Paulo: Martins Fontes.

Wallon, H. (1978). A evolução psicológica da criança. São Paulo: Edições 70.

Recebido em 00.00.2000 Aceito em 00.00.2000 